\title{
Efektivitas Wedang Jahe Dan Daun Mint Untuk Mengurangi Mual Muntah Pada Ibu Hamil di PMB YF Kota Bukittinggi Tahun 2017
}

\author{
Detty Afriyanti $S$ 1) \\ ${ }^{1}$ Prodi D IV Kebidanan, STIKes Fort De Kock, Bukittinggi \\ email: afriyantidetty@gmail.com
}

Submitted: 20-07-2017, Reviewer: 25-08-2017, Accepted: 30-12-2017

\begin{abstract}
Nausea and vomiting in Pregnant Women is a normal complaint that is often experienced by First Trimester Pregnant Women. Nausea, vomiting that occurs in the first trimester of pregnancy is due to an increase in levels of the hormones Esterogen and Human Chorionic Gonadotropine (HCG) in the serum of the placenta. The purpose of this study was to determine the effectiveness of giving ginger and mint leaves to pregnant women with the first trimester emesis gravidarum.

The research design used was quasy experiment with a two group design approach. The population used in this study were all pregnant women with emesis gravidarum with a total sample of 21 people, of which 7 were given ginger and 7 people were given mint leaves. Data collection with observation sheets with data analysis using $t$-test.

Based on the results of the study, the average frequency of vomiting before consuming ginger 5.86 and after 3.71. Based on statistical tests, there is an effect of mint leaf consumption on the frequency of nausea and vomiting in first trimester pregnant women with emisis gravidarum. The average frequency of vomiting before consuming mint leaves 5.29 times a day and after 3.57 times a day. Anova test results obtained there is an influence of consumption of ginger and mint leaves on the frequency of nausea and vomiting in the first trimester of pregnant women with emisis gravidarum.

Based on the results of the study, it is expected that the administration of ginger and mint leaves is very effective in reducing the frequency of nausea and vomiting in pregnant women with emisis gravidarum; as an alternative before using antiemetic drugs, and making ginger and mint leaves as an herbal treatment to treat nausea and vomiting in First Trimester Pregnant Women with emisis gravidarum
\end{abstract}

\begin{abstract}
Abstrak
Mual dan muntah pada Ibu Hamil merupakan keluhan normal yang sering dialami Ibu Hamil Trimester Pertama. Mual muntah yang terjadi pada kehamilan trimester pertama disebabkan karena terdapat peningkatan kadar hormon Esterogen dan Human Chorionic Gonadotropine (HCG) dalam serum dari plasenta. Tujuan penelitian ini adalah untuk mengetahui efektivitas pemberian wedang jahe dan daun mint pada Ibu Hamil dengan emesis gravidarum Trimester pertama.

Desain penelitian yang digunakan adalah quasy eksperimen dengan rancangan pendekatan two group design. Populasi yang digunakan dalam penelitian ini adalah keseluruhan Ibu Hamil dengan emesis gravidarum dengan jumlah sampel sebanyak 21 orang, yang terbagi 7 orang diberikan wedang jahe dan 7 orang diberikan daun mint. Pengumpulan data dengan lembar observasi dengan analisa data dengan mengunakan uji t-test.

Berdasarkan hasil penelitian diperoleh, rerata frekuensi muntah sebelum mengkonsumsi wedang jahe 5,86 dan sesudah menjadi 3,71. Selanjutnya, terdapat pengaruh konsumsi daun mint terhadap frekuensi mual muntah Ibu Hamil Trimester pertama dengan emisis gravidarum. Rerata frekuensi muntah sebelum mengkonsumsi daun mint 5,29 kali sehari dan sesudah 3,57 kali sehari. Hasil uji anova diperoleh terdapat pengaruh konsumsi wedang jahe dan daun mint terhadap frekuensi mual muntah Ibu Hamil Trimester pertama dengan emisis gravidarum

Berdasarkan hasil penelitian, diharapkan pemberian wedang jahe dan daun mint sangat efektif dalam mengurangi frekuensi mual muntah pada Ibu Hamil dengan emisis gravidarum; sebagai alternative sebelum menggunakan obat antiemetik, dan menjadikan wedang jahe dan daun mint sebagai penanganan herbal untuk mengatasi mual muntah pada Ibu Hamil Trimester Pertama deng an emisis gravidarum
\end{abstract}


Kata Kunci : Daun Mint, Ibu Hamil, Mual Muntah, Wedang Jahe

\section{PENDAHULUAN}

Kehamilan menyebabkan perubahan fisik, psikis dan hormonal pada tubuh Ibu Hamil. Hal tersebut menimbulkan mual muntah (morning sickness) yang biasa terjadi pada awal kehamilan (Iriati, 2014). Mual muntah merupakan salah satu gejala paling awal, paling umum dan paling menyebabkan stress yang dikaitkan dengan kehamilan (Tiran, 2009). Hampir 50-90\% perempuan hamil mengalami mual muntah pada trimester pertama. Mual dan muntah seringkali diabaikan karena dianggap sebagai sebuah konsekuensi diawal kehamilan (Aritonang 2010p ; 47).

Kehamilan mempengaruhi tubuh Ibu Hamil dengan menimbulkan perubahanperubahan fisiologi yang terjadi diseluruh sistem organ, sebagian besar perubahan pada tubuh Ibu Hamil disebabkan oleh kerja hormonal. Perubahan ini terjadi akibat ketidakseimbangan hormon progestrogen dan estrogen yang ada didalam tubuh Ibu Hamil (Mandriwati, 2008). Beberapa keluhan yang membuat Ibu Hamil merasa tidak nyaman diantaranya adalah mual dan muntah (Smith, dkk,2009). Wanita hamil sebanyak $50 \%$ mengalami emesis gravidarum yang dikenal dengan istilah Morning Sickness (rasa mual di pagi hari) menjadi bagian yang 'tidak enak' dalam kehamilan (Koesno, 2009 p ; 56).

Emesis gravidarum ini menyebabkan penurunan nafsu makan, sehingga terdapat perubahan keseimbangan elektrolit dengan kalium, kalsium, dan natrium yang menyebabkan perubahan metabolisme tubuh (Neil \& Nelson,2006). Emesis gravidarum akan bertambah berat menjadi hiperemesis gravidarum yang menyebabkan Ibu Hamil muntah terus menerus tiap kali minum atau makan, akibatnya tubuh Ibu Hamil semakin lemah, pucat, dan frekuensi buang air kecil menurun drastis, sehingga cairan tubuh berkurang dan darah menjadi kental (hemokonsentrasi) sehingga melambatkan peredaran darah yaitu oksigen dan jaringan sehingga dapat menimbulkan kerusakan jaringan yang dapat membahayakan kesehatan ibu dan perkembangan janin yang dikandungnya (Hidayati, 2009).

Mual dan muntah pada kehamilan biasanya bersifat ringan dan merupakan kondisi yang dapat dikontrol sesuai dengan kondisi Ibu Hamil. Kondisi tersebut terkadang berhenti pada trimester pertama, namun pengaruhnya dapat menimbulkan gangguan nutrisi, dehidrasi, kelemahan, penurunan berat badan, serta ketidakseimbangan elektrolit (Runiari, 2010). Mual muntah yang terjadi pada kehamilan yang disebabkan karena terjadi peningkatan kadar hormon estrogen dan progesterone yang diproduksi oleh Human Chorionic Gonadotropine (HCG) dalam serum dari plasenta. Frekuensi terjadinya morning sickness tidak hanya di pagi hari melainkan bisa siang bahkan malam hari (Aritonang, 2010). Selain itu karena mencium aroma suatu masakan, setengah dari perempuan hamil pasti akan mengalami mual muntah.

Menurut World health organization (WHO), jumlah kejadian hiperemesis gravidarum mencapai $12,5 \%$ dari jumlah seluruh kehamilan di dunia. Mual dan muntah dapat mengganggu dan membuat ketidak seimbangan cairan pada jaringan ginjal dan hati menjadi nekrosis (WHO, 2013).

Berdasarkan hasil penelitian di Indonesia, diperoleh data Ibu Hamil dengan keluhan mual dan muntah terjadi pada $60-80 \%$ primigravida dan 60-40 \% multigravida. Satu diantara seribu kehamilan gejala-gejala ini menjadi lebih berat. Perasaan mual ini disebabkan oleh karena meningkatnya kadar 
hormon estrogen dan Hormon Chorionic Gonadotropin (HCG) dan serum perubahan fisiologis kenaikan hormon ini belum jelas, mungkin karena sistem saraf pusat dan pengosongan lambung yang berkurang (Depkes RI, 2013).

Mual dan muntah pada kehamilan biasanya bersifat ringan dan merupakan kondisi yang dapat dikontrol sesuai dengan kondisi Ibu Hamil. Kondisi tersebut terkadang berhenti pada trimester pertama, namun pengaruhnya dapat menimbulkan gangguan nutrisi, dehidrasi, kelemahan, penurunan berat badan, serta ketidakseimbangan elektrolit (Runiari, 2010). Mual dan muntah pada kehamilan berlebih atau hiperemesis gravidarum tidak hanya mengancam kehidupan Ibu Hamil, namun juga dapat menyebabkan efek samping pada janin seperti abortus, bayi lahir rendah, kelahiran prematur, serta malforasi pada bayi baru lahir. Kejadian pertumbuhan janin terhambat (Intrauterine growth retardation/IUGR) meningkat pada wanita hamil dengan hiperemesis gravidarum.

Mual muntah tingkat I (ringan) mual muntah terus menerus menyebabkan lemah, tidak mau makan, berat badan turun dan rasa nyeri epigastrium, tekanan darah turun, turgor kulit kurang, lidah kering dan mata cekung. Tingkat II (sedang) mual dan muntah yang hebat menyebabkan keadaan umum penderita lebih parah yaitu apatis, turgor kulit mulai jelek, lidah kering dan kotor, nadi kecil dan cepat, dehidrasi, berat badan turun, mata cekung. Tingkat III (berat) keadaan umum jelek, kesadaran sangat menurun, sampai koma, nadi kecil halus dan cepat, dehidrasi hebat, suhu badan naik dan tekanan darah turun, komplikasi yang dapat berakibat fatal terjadi pada susunan syaraf pusat dengan adanya perubahan mental dll.(Runiari 2010 hal 58)

Secara farmakologi untuk mengatasi mual muntah pada kehamilan salah satunya adalah piridoksin (vitamin B6) yang mengalami mual muntah dalam kehamilan. Tetapi non farmakologi dilakukan dengan cara pengaturan diet pada Ibu Hamil, dukungan emosional, dan akupresure. (Runiari \& Imaningrum, 2012). Terapi non farmakologi lainnya dengan mengkonsumsi lemon, pisang kapok, jahe, daun mint, yang banyak kandungan flavonoid serta vitamin B6 yang mampu mengatasi mual dan muntah pada kehamilan. Faktor-faktor yang bisa mengurangi emesis gravidarum salah satunya yaitu jahe dan daun mint.(Ehiowemwenguan, 2014).

Menurut Rahingtyas (2008) dan Booth(2004), sebanyak 80\% Ibu Hamil yangmengalami mual muntah terjadi pada trimester I dan 2\% Ibu Hamil pada trimester 1 mengalami masalah mual dan muntah yang berat, sehingga diperlukan perawatan medis. Rasa mual pada awal kehamilan dapat di kurangi dengan menggunakan terapi komplementer antara lain dengan tanaman herbal atau tradisional yang bisa dilakukan dan mudah di dapatkan seperti jahe,daun peppermint, lemon, dll (Ira, 2012). Selain, mengkonsumsi obat-obatan untuk mengatasi mual muntah, para Ibu Hamil bisa mencoba berbagai ramuan tradisional seperti jahe yang dapat mengatasi mual muntah dengan cara diseduh. Ibu Hamil saat ini cenderung malas untuk meminum seduhan jahe dengan alasan tidak menyukai aromanya dan malas membuatnya.

Kandungan jahe terdapat pada minyak Atsiri Zingiberena (zingirona), zingiberol, bisa bilena, kurkumen, gingerol,flandrena, vit A dan resin pahit yang dapat memblok serotinin yaitu suatu neurotransmitter yang di sintesiskan pada neuron-neuron serotonergis dalam sistim syaraf pusat dan sel-sel enterokromafin dalam saluran pencernaan, sehingga sebagai pemberi perasaan nyaman dalam perut, sehingga dipercaya sebagai pemberi perasaan nyaman dalam perut (Ahmad, 2013). Jika ibu tidak 
menyukai seduhan jahe, maka Ibu Hamil bisa meminum seduhan daun Peppermint (mint) sebagai penggantinya. Peppermint (daun mint) juga diketahui bisa menjadi obat yang aman dan efektif untuk mengobati mual dan muntah pada Ibu Hamil. Peppermint bisa dimakan seperti permen mint, minum teh Peppermint /menggunakan minyak peppermint (Elshabrina, 2013). Sebuah studi dari Wheeling Jesuit University, USA, menyimpulkan orang yang mengkonsumsi peppermint cenderung sama dengan makan 2.800 kalori lebih sedikit setiap minggu di bandingkan mereka yang tidak mengkonsumsi peppermint.

Daun mint juga mengandung menthol yang dapat mempercepat sirkulasi, meringankan kembung, mual dan kram. Daun mint mengandung minyak atsiri yaitu menthol yang berpotensi memperlancar sistem pencernaan dan meringankan kejang perut atau kram, karena memiliki efek anastesi ringan serta mengandung efek karminatif dan antispasmodik yang bekerjadi usus halus pada saluran gastrointestinal, sehingga mampu mengatasi atau menghilangkan mual muntah (Tiran, 2008; Parwitasari, 2014).

Berdasarkan hasil penelitian Ayu Dwi Putri at all 2014, tentang Efektifitas

\section{METODE PENELITIAN}

Desain penelitian yang digunakan adalah quasy eksperimen dengan rancangan pendekatan two group design. Populasi yang digunakan dalam penelitian ini adalah keseluruhan Ibu Hamil dengan emesis gravidarum dengan jumlah sampel sebanyak
Pemberian Jahe Hangat Dalam Mengurangi Frekuensi Mual Muntah Pada Ibu Hamil Trimester I, menyebutkan sebelum diberi intervensi rerata responden mengalami frekuensi mual muntah sebanyak 13 kali dalam sehari, setelah diberi intervensi minuman jahe hangat rata-rata frekuensi mual muntah menurun menjadi 3,18 kali dalam sehari dengan nilai $\mathrm{p}=0,000$. Hasil penelitian ini dapat disimpulkan, minuman jahe hangat memberikan pengaruh terhadap penurunan frekuensi mual muntah pada Ibu Hamil TM I. Selanjutnya, berdasarkan hasil penelitian Ratih Indah Kartikasari at all 2016, tentang Aromaterapi Pappermint untuk MenurunkanMual Dan Muntah Pada Ibu Hamildijelaskan bahwa sebelum diberikan aromaterapipappermint lebih dari sebagian $(70 \%)$ responden mengalami muntah dengan frekuensi 4-6 x/ hari.Setelah diberikan aromaterapi pappermint hampir seluruhnya $(95 \%)$ responden mengalami muntahdengan frekuensi 1-3 x/ hari.

Berdasarkan uraian permasalahan tersebut diatas, maka peneliti tertarik untuk meneliti efektivitas pemberian wedang jahe dan daun mint pada Ibu Hamil dengan emesis gravidarum trimester I di PMB "YF" Kota Bukittinggi tahun 2017.

21 orang, yang terbagi 7 orang diberikan wedang jahe dan 7 orang diberikan daun mint. Pengumpulan data dengan lembar observasi dengan analisa data dengan mengunakan uji t-test.

\section{HASIL DAN PEMBAHASAN}

Tabel 1

\section{Rerata Frekuensi Mual Muntah Sebelum Diberikan Wedang Jahe Pada Ibu Hamil} Trimester I Di PMB “YF” Kota B ukittinggi Tahun 2017

\begin{tabular}{llllll} 
Kategori & N & Minimum & Maximum & Mean & Std. Deviation \\
\hline
\end{tabular}




\begin{tabular}{llllll}
\hline Pre Wejang Jahe & 7 & 4 & 8 & 5.86 & 1.345 \\
\hline
\end{tabular}

Tabel 2

Rerata Frekuensi Mual Muntah Sesudah Diberikan Wedang Jahe Pada Ibu Hamil Trime ster I Di PMB "YF" Kota B ukittinggi Tahun 2017

\begin{tabular}{cccccc}
\hline Kategori & N & Minimum & Maximum & Mean & Std. De viation \\
\hline Post Wejang Jahe & 7 & 3 & 5 & 3.71 & 0.951 \\
\hline
\end{tabular}

Tabel 3

Rerata Frekuensi Mual Muntah Sebelum Sesudah Diberikan Wedang Jahe Pada Ibu Hamil Trimester I Di PMB "YF" Kota B ukittinggi Tahun 2017

\begin{tabular}{|c|c|c|c|c|c|c|c|c|c|}
\hline \multicolumn{10}{|c|}{ Paired Samples Test } \\
\hline & & \multicolumn{5}{|c|}{ Paired Differences } & \multirow[b]{3}{*}{$t$} & \multirow[b]{3}{*}{ df } & \multirow[b]{3}{*}{ Sig. (2-tailed) } \\
\hline & & \multirow[b]{2}{*}{ Mean } & \multirow[b]{2}{*}{ Std. Deviation } & \multirow{2}{*}{$\begin{array}{c}\text { Std. Error } \\
\text { Mean }\end{array}$} & \multicolumn{2}{|c|}{$\begin{array}{l}95 \% \text { Confidence } \\
\text { Interval of the } \\
\text { Difference } \\
\end{array}$} & & & \\
\hline & & & & & Lower & Upper & & & \\
\hline $\begin{array}{l}\text { Pair } \\
1\end{array}$ & $\begin{array}{l}\text { sebelum diberikan } \\
\text { wedang jahe - sesudah } \\
\text { diberikan wedang jahe }\end{array}$ & 2,14 & ,690 & ,261 & 1,50 & 2,78 & 8,216 & 6 & ,000 \\
\hline
\end{tabular}

Berdasarkan hasil penelitian menggunakan uji statistik T-Test didapatkan nilai sig $=0,000<0,05(\alpha)$ artinya ada pengaruh konsumsi wedang jahe terhadap frekuensi mual muntah ibu hamil trimester pertama. Rata-rata frekuensi muntah ibu hamil trimester I sebelum mengkonsumsi wedang jahe 5,86 kali sehari dan standar deviasi 1,345, dengan frekuensi mual muntah terendah yaitu 4 dan tertinggi 7 . Akan tetapi sesudah diberikan wedang jahe rata-rata frekuensi muntah menjadi 3,71 kali sehari dengan dan standar deviasi 0,951 . Frekuensi terendah 2 dan tertinggi 5.

Menurut Rahingtyas (2008) dan Booth (2004), sebanyak 80\% Ibu Hamil yang mengalami mual muntah terjadi pada trimester I kehamilan dan 2\% Ibu Hamil pada trimester I mengalami masalah mual dan muntah yang berat sehingga diperlukan perawatan medis. Rasa mual pada awal kehamilan dapat di kurangi dengan menggunakan terapikomplementer antara lain dengan tanaman herbal atau tradisional yang bisa dilakukan dan mudah di dapatkan seperti jahe, daun peppermint, lemon, dan lain-lain (Ira, 2012; Parwitasari, 2014).

Hasil analisa diatas sebelum diberi intervensi berupa pemberian wedang jahe menunjukkan bahwa sebagian besar ibu hamil TM I mengalami keluhan mual muntah.Hal ini didukung oleh teori yang menyatakan bahwa hampir 50-90\% perempuan hamil mengalami mual muntah pada trimester pertama.Mual muntah seringkali diabaikan karena dianggap sebagai sebuah konsekuensi diawal kehamilan.

Jahe berkhasiat sebagai antimuntah dan dapat digunakan para ibu hamil mengurangi morning sickness.Penelitian menunjukkan bahwa jahe sangat efektif menurunkan metoklopamid senyawa penginduksi mual dan muntah (Hasanah, 2014).Keungulan 
pertama jahe adalah kandungan minyak atsiri yang mempunyai efek menyegarkan dan memblokir reflek muntah, sedang gingerol dapat melancarkan darah dan sarafsaraf bekerja dengan baik. Hasilnya ketegangan bisa dicairkan, kepala jadi segar, mual muntah pun ditekan. Aroma harum jahe dihasilkan oleh minyak atsiri, sedangkan oleoresisnya menyebabkan rasa pedas yang menghangatkan tubuh dan mengeluarkan keringat (Hernani, 2013; Putri 2017).

Hal ini didukung oleh hasil penelitian Saswita (2013) bahwa jahe dapat mencegah mual dan muntah karena jahe mampu menjadi penghalang serotonin, sebuah senyawa kimia yang dapat menyebabkan perut berkontraksi, sehingga timbul rasa mual. Jahe efektif dalam mengurangi mual dan muntah selama kehamilan trimester I, yang dibuktikan dengan hasil uji hipotesis adanya penurunan rata-rata penurunan mual dan muntah sebelum intervensi sebesar 3,87 dan setelah diberikan intervensi $2,78 \mathrm{p}$-value $0,0014(<\alpha=0,05)$

Peneliti berasumsi bahwa dari penelitian yang dilakukan terlihat adanya perbedaan rata-rata frekuensi mual muntah ibu hamil trimesterpertama sebelum dan sesudah diberikan intervensi wedang jahe. Hal ini menunjukkan bahwa wedang jahe dapat efektif mengurangi intensitas emesis gravidarum pada ibu hamil trimester pertama.

Tabel 4

Rerata Frekuensi Mual Muntah Sebe lum Diberikan Daun Mint Pada Ibu Hamil Trimester Pertama Di PMB "YF" Kota Bukittinggi Tahun 2017

\begin{tabular}{cccccc}
\hline Kategori & N & Minimum & Maximum & Mean & Std. Deviation \\
\hline Pre Daun Mint & 7 & 4 & 7 & 5.29 & 1.113 \\
\hline
\end{tabular}

Tabel 5

Rerata Frekuensi Mual Muntah Sesudah Dibe rikan Daun Mint Pada Ibu Hamil Trime ster I Di PMB "YF" Kota B ukittinggi Tahun 2017

$\begin{array}{lllll}\text { Kategori } & \text { N } & \text { Minimum Maximum Mean Std. Deviation }\end{array}$

\begin{tabular}{llllll}
\hline Post Daun Mint & 7 & 2 & 5 & 3.57 & 0.976
\end{tabular}




\section{Tabel 6}

\section{Uji T-Test Pre -Post Konsumsi Daun Mint Rerata Frekuensi Mual Muntah Sebelum Sesudah Dibe rikan Daun Mint Pada Ibu Hamil Trimester I Di PMB "YF" Kota Bukittinggi Tahun 2017}

\begin{tabular}{|c|c|c|c|c|c|c|c|c|c|}
\hline & & \multicolumn{5}{|c|}{ Paired Differences } & \multirow[b]{3}{*}{ t } & \multirow[b]{3}{*}{ df } & \multirow[b]{3}{*}{ Sig. (2-tailed) } \\
\hline & & \multirow[b]{2}{*}{ Mean } & \multirow[b]{2}{*}{ Std. Deviation } & \multirow{2}{*}{$\begin{array}{l}\text { Std. Error } \\
\text { Mean }\end{array}$} & \multicolumn{2}{|c|}{$\begin{array}{l}95 \% \text { Confidence } \\
\text { Interval of the } \\
\text { Difference }\end{array}$} & & & \\
\hline & & & & & Lower & Upper & & & \\
\hline & $\begin{array}{l}\text { sebelum diberikan } \\
\text { daun mint - sesudah } \\
\text { diberikan daun mint }\end{array}$ & 1,71 & 488 & 184 & 1,26 & 2,17 & 9,295 & 6 & ,000 \\
\hline
\end{tabular}

Berdasarkan hasil penelitian dengan menggunakan uji statistik dengan T-Test didapatkan nilai sig $=0,000<0,05(\alpha)$ artinya ada pengaruh konsumsi daun mint terhadap frekuensi mual muntah ibu hamil trimester pertama. Rata-rata frekuensi muntah ibu hamil trimester I sebelum mengkonsumsi daun mint 5,29 kali sehari dan standar deviasi 1,113, dengan frekuensi mual muntah terendah yaitu 4 dan tertinggi 7. Akan tetapi sesudah diberikan daun mint rata-rata frekuensi muntah menjadi 3,57 kali sehari dengan dan standar deviasi 0,976. Frekuensi terendah 2 dan tertinggi 5.

Mual dan muntah pada kehamilan sering juga disebut "morning sickness".Akan tetapi, hanya terdapat sekitar $17 \%$ ibu hamil yang melaporkan mengalami mual dan muntah hanya di pagi hari. Sebuah penelitian prospektif yang melibatkan 160 ibu menemukan bahwa $74 \%$ ibu melaporkan mengalami mual dengan durasi rata-rata selama 34,6 kali dalam sehari, morning sickness terjadi hanya pada $1,8 \%$ dan $80 \%$ ibu melaporkan mengalami mual yang berlangsung sepanjang hari (Pramita, 2016).

Peppermint (Daun Mint) juga diketahui bisa menjadi obat yang aman dan efektif untuk mengobati mual dan muntah pada ibu hamil.Peppermint bisa dimakan seperti permen mint, minum the daun mint atau menggunakan minyak peppermint (Elshabrina, 2013; Parwitasari 2014).

Sebuah studi dari Wheeling Jesuit University,US, menyimpulkan bahwa orang yang mengkonsumsi peppermint secara rutin cenderung sama dengan makan 2.800 kalori lebih sedikit setiap minggu di bandingkan mereka yang tidak. Daun mint juga mengandung menthol yang dapat mempercepat sirkulasi, meringankan kembung, mual dan kram. Daun mint mengandung minyak atsiri yaitu menthol yang berpotensi memperlancar sistem pencernaan dan meringankan kejang perut atau kram karena memiliki efek anastesi ringan serta mengandung efek karminatif dan anti pasmodik yang bekerja di usus halus pada saluran gastrointestinal sehingga mampu mengatasi atau menghilangkan mual muntah (Tiran, 2008).

Sejalan dengan penelitian yang dilakukan Parwitasari tahun 2014 tentang perbandingan efektivitas pemberian seduhan jahe dan daun mint terhadap mual muntah pada ibu hamil, didapatkan nilai rata-rata intensitas derajat mual muntah ibu hamil sebelum diberikan seduhan daun mint adalah 3,20 dengan standar deviasi 0,862 dan 2,60 rata-rata intensitas mual muntah sesudah pemberian seduhan daun mint dengan standar deviasi 0,828. Perbedaan nilai mean pretest dan postest pada 
kelompok eksperimenmpemberian seduhan daun mint adalah sebesar 0,6. Hasil analisa diperoleh $\mathrm{p}(0,003)<\alpha(0,05)$, maka dapat disimpulkan adaperbedaan yang signifikan antara mean intensitas derajat mual muntah sebelum dan setelah pemberian seduhan daun mint.

Peneliti berasumsi bahwa dari penelitian yang dilakukan diperoleh cukup efektif penurunan intensitas mual muntah ibu hamil TM I dengan intervensi daun mint dimana pada tabel 5.3 diperoleh rata-rata frekuensi mual muntah ibu hamil TM I yaitu 3,46. Pemberian daun mint merupakan salah satu alternatif dalam mengurangi mual muntah. Daun mint mempunyai kandungan menthol yang mana zat tersebut dapat mengurangi rasa mual.

\section{Tabel 7}

Perbedaan Rerata Frekuensi Mual Muntah Ibu Hamil TM I Terhadap Pengaruh Wedang Jahe dan Daun Mint Di PMB "YF" Kota B ukittinggi Tahun 2017

\begin{tabular}{|c|c|c|c|c|}
\hline \multirow{2}{*}{ Kelompok } & \multicolumn{2}{|c|}{$\begin{array}{c}\text { Rata-rata Frekeunsi } \\
\text { Mual dan Muntah }\end{array}$} & $\begin{array}{c}\text { Standar } \\
\text { De viasi Pre }\end{array}$ & $\begin{array}{c}\text { Standar } \\
\text { De viasi Post }\end{array}$ \\
\cline { 2 - 3 } & Sebelum & Sesudah & & \\
\hline Wedang Jahe & 5,86 & 3,71 & 1,345 & 0,951 \\
\hline Daun mint & 5,29 & 3,57 & 1,113 & 0,952 \\
\hline
\end{tabular}

Berdasarkan tabel 7 , rerata frekuensi muntah Ibu Hamil TM I sebelum mengkonsumsi wedang jahe 5,86 kali sehari dengan standar deviasu 1,345, akan tetapi sesudah diberikan wedang jahe frekuensi muntah menjadi 3,71 kali sehari dengan standar deviasi 0,951. Sedangkan pada daun mint rata-rata mual dan muntah Ibu Hamil TM I sebelum diberikan daun mint sebanyak 5,29 kali sehari dengan standar deviasu 1,113, akan tetapi setelah diberikan daun mint frekuensi muntah menjadi 3,57 kali sehari dengan standar deviasi 0,952 .

Mual muntah dalam kehamilan disebut juga morning sickness gejala ini muncul sekitar minggu ke 4-9 kehamilan, mencapai puncak pada minggu ke 7-12 kehamilan.Penyebab terjadinya emesis gravidarum sampai saat ini tidak dapat diketahui secara pasti. Ada yang mengatakan bahwa perasaan mual disebabkan oleh karena meningkatnya kadar hormon estrogen dan HCG (Hormon Chorionic Gonadotrophine) dalam serum (Prawiohardjo.2008)
Jahe merupakan terna tahunan, berbatang semu dengan panjang $30-75 \mathrm{~cm}$. Jahe hampir tersebar diseluruh tropika basah, termasuk Indonesia.Sedikitnya ada 115 kandungan zat aktif di dalam jahe yangmempunyai efek farmakologis bagi tubuh, salah satunya antiemetik.Oleh karena itu, jahe memiliki khasiat untuk dapat mengatasi mual dan muntah dalam kehamilan melalui zat aktif yang dikandungnya yaitu gingerols, shoagols, galanolactone, dan terpenoid.Untuk mengatasi mual dan muntah dapat mengkonsumsi jahe dalam berbagai bentuk sedian seperti wedang jahe.Dosis jahe yang digunakan tidak boleh melebihi 4 gram per hari agar dapat menghindari efek samping (Masruroh, 2016).

Kandungan di dalam jahe terdapat minyak atsiri Zingiberena (zingirona), zingiberol, bisabilena, kurkumen, gingerol, flandrena, vit A dan resin pahit yang dapat memblok serotinin yaitu suatu neurotransmitter yang di sintesiskan pada neuron-neuron serotonergis dalam sistem 
saraf pusat dan sel-sel enterokromafin dalam saluran pencernaan sehingga di percaya dapat sebagai pemberi perasaan nyaman dalam perut sehingga di percaya sebagai pemberi perasaan nyaman dalam perut sehingga dapat mengatasi mual muntah (Ahmad 2013; Prawitasari 2014).

Hal ini sesuai dengan penelitian Saswita (2013) bahwa jahe dapat mencegah mual dan muntah karena jahe mampu menjadi penghalang serotonin, sebuah senyawa kimia yang dapat menyebabkan perut berkontraksi, sehingga timbul rasa mual. Jahe efektif dalam mengurangi mual dan muntah selama kehamilan trimester I, yang dibuktikan dengan hasil uji hipotesis adanya penurunan rata-rata penurunan mual dan muntah sebelum intervensi sebesar 3,87 dan setelah diberikan intervensi $2,78 \mathrm{p}$-value $0,0014(<\alpha=0,05)$.

Peppermint (Daun Mint) juga diketahui bisa menjadi obat yang aman dan efektif untuk mengobati mual dan muntah pada ibu hamil.Peppermint bisa dimakan seperti permen mint, minum teh daun mint atau menggunakan minyak peppermint (Elshabrina, 2013; Parwitasari 2014).

Sebuah studi dari Wheeling Jesuit University,US, menyimpulkan bahwa orang yang mengkonsumsi peppermint secara rutin cenderung sama dengan makan 2.800 kalori lebih sedikit setiap minggu di bandingkan mereka yang tidak. Daun mint juga mengandung menthol yang dapat mempercepat sirkulasi, meringankan kembung, mual dan kram. Daun mint mengandung minyak atsiri yaitu menthol yang berpotensi memperlancar sistem pencernaan dan meringankan kejang perut atau kram karena memiliki efek anastesi ringan serta mengandung efek karminatif dan antispasmodik yang bekerja di usus halus pada saluran gastrointestinal sehingga mampu mengatasi atau menghilangkan mual muntah (Tiran, 2008).

Daun mint memiliki kandungan menthol. Daun mint ini juga sangat cocok dijadikan sahabat untuk ibu hamil. Karena daun mint mampu meredakan rasa mual yang memang erat kaitannya dengan morning sickness yang sering di alami oleh wanita yang tengah hamil (Halo Sehat 2015).

Menurut asumsi peneliti pada pemberian wedang jahe dan rebusan daun mint, responden lebih mudah menerima presepsi tentang wedang jahe dibandingkan rebusan daun mint.Hal ini dikarenakan jahe telah umum digunakan sehari-hari oleh responden dan sudah tidak asing lagiuntuk diketahui, jahe juga sangat mudah didapatkan dipasaran dan sebagian responden juga telah mengetahui tentang khasiat jahe yang dapat dijadikan sebagai alternatif untuk mengatasi mual. Pada daun mint responden masih membutuhkan lebih banyak penjelasan tentang hal ini, dikarenakan daun mint masih sedikit asing dikeseharian untuk dikonsumsi dan beberapa responden masih baru mengetahui bagaimana bentuk dari daun mint tersebut. Tetapi tingkat penasaran responden tentang hal ini cukup tinggi, dan responden dapat menerima presepsi bahwa daun mint juga dapat digunakan sebagai alternatif herbal untuk mengatasin mual muntah dalam kehamilan.Dapat disimpulkan bahwa jahe lebih efektif untuk digunakan sebagai alternatif herbal untuk mengatasi mual muntah dalam kehamilan karena dapat dengan mudah diterima oleh presepsi responden dan sangat mudah untuk didapatkan. 


\section{SIMPULAN}

1. Terdapat pengaruh konsumsi wedang jahe terhadap frekuensi mual muntah Ibu Hamil TM I

2. Terdapat pengaruh konsumsi daun mint terhadap frekuensi mual muntah Ibu Hamil TM I

\section{REFERENSI}

Ratih Indah Kartikasari, Faizatul Ummah, Lutfi Barrotut Taqiiyah. 2017. Aromaterapi Pappermint Untuk Menurunkan Mual Dan Muntah Pada Ibu Hamil

Chatur Dhian Parwitasari, Sri Utami, Siti Rahmalia. 2014. Perbandingan Efektivitas Pemberian Rebusan Jahe Dan Daun Mint Terhadap Mual Muntah Pada Ibu Hamil

Ayu Ardani. 2014. Perbandingan Efektifitas Pemberian Terapi Minuman Jahe Dengan Minuman Kapulaga Terhadap Morning Sickness Pada Ibu Hamil Trimester I Dikelurahan Ngempon Kecamatan Bergas Kabupaten Semarang

Zahratul Aini. 2010. Pengaruh Pemberian Air Rebusan Jahe Terhadap Mual Muntah Pada Ibu Yang Mengalami Emesis Gravidarum Di Wilayah Kerja Puskesmas Wirobrajan Yogyakarta

Ahmad, J. 2013. Aneka Manfaat Ampuh Rimpang Jahe Untuk Pengobatan. Yogyakarta: Dandra Pustaka Indonesia.

Alyamaniyah. Ummi Hasanah. Mahmudah. 2014. Efektivitas Pemberian Wedang Jahe Terhadap Penurunan Emesis
3. Terdapat pengaruh konsumsi wedang jahe na daun mint terhadap frekuensi mual muntah Ibu Hamil TM I

Gravidarum Pada Trimester Pertama. Surabaya: Departemen Biostatistika dan Kependudukan.

Aritonang, E. 2010. Kebutuhan Gizi Ibu Hamil. Medan: Kampus IPB Taman Kencana Bogor.

Budhwaar, Vikaas. 2006. Khasiat Rahasia Jahe dan Kunyit. Jakarta: Bhuana Ilmu Populer.

Dinas Kesehatan Kota Padang. 2016. Halo,Sehat.2015. Kegunaan tumbuhan disekitar lingkungan. Dikutip dari www.halosehat.com

Hernani. Winarti. Christina. 2013. Kandungan Bahan Aktif Jahe dan Pemanfaatannya dalam Bidang Kesehatan. Bogor: Balai Besar Penelitian dan Pengembangan Pascapanen Pertanian.

Hidayat, AAA. 2014. Metode Penelitian Kebidanan Dan Teknik Analisis Data. Jakarta: Salemba Medika.

Iriati, B., et al., et al. 2014. Asuhan Kehamilan Berbasis Bukti. Jakarta: Agung Seto.

Kriebs, Jan M. 2010. Buku Saku Asuhan Kebidanan Varney Edisi 2. Jakarta:EGC 
Lamadhah, Athif. 2006. Buku Pintar Kehamilan dan Melahirkan. Jogjakarta: Diva Press.

Manuaba, IBG, dkk,. 2010. Pengantar Kuliah Obstetri. Jakarta: EGC

Masruroh, S. 2016. Khasiat untuk Mengatasi Mual dan Muntah Pada Wanita Hamil. Lampung.

Notoatmodjo. 2012. Metodologi Penelitian Kesehatan. Jakarta : Rineka Cipta

Parwitasari, Chatur Dhian, Utami, Sri and Rahmalia, Siti. 2014. Perbandingan Efektivitas Pemberian Rebusan Jahe dan Daun Mint Terhadap Mual Muntah pada Ibu Hamil. Dikutip dari www.digilib.unimus.ac.id.

Pratami, Evi. 2016. Evidence-Based dalam Kebidanan; Kehamilan, Persalinan, Nifas. Jakarta: EGC

Prawirohardjo. 2009. Ilmu Kebidanan. Jakarta: PT Bina Pustaka

Putri, Ayu Dwi. 2017. Efektifitas Pemberian Jahe Hangat Dalam Mengurangi Frekuensi Mual Muntah Pada Ibu Hamil Trimester I. Parepare Sulawesi Selatan

Profil Kesehatan Indonesia. 2013.

Runiari, Nengah. 2010. Asuhan Keperawatan Pada Klien Dengan Hiperemesis Gravidarum. Jakarta : Salemba Medika.

Saswita. 2013. Efektifitas Jahe Dalam Menguragi Emesis Gravidarum pada Ibu Hamil Trimester I : Jurnal Ners Indonesia, Vol 2.
Setyawan, Budi. 2015. Budidaya Jahe. Yogyakarta: Pustaka Baru Press.

Tiran D. 2009. Mual dan Muntah Kehamilan: Seri Asuhan Kebidanan. Jakarta: Kedokteran EGC.

Wiknjosastro, Hanifa. 2009. Ilmu Kandungan. Jakarta: Yayasan Bina Pustaka Sarwono Prawirohardjo. 